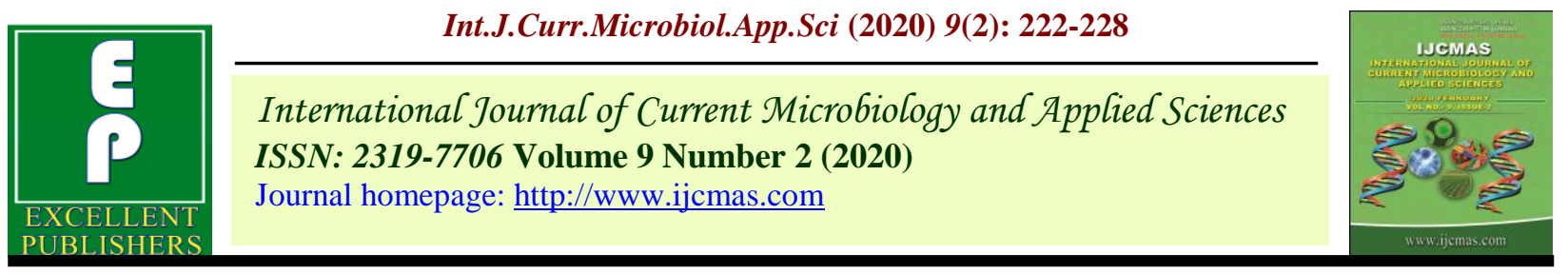

Original Research Article

https://doi.org/10.20546/ijcmas.2020.902.028

\title{
Genetic Diversity of Coriander for Yield and its Attributing Characters
}

\author{
Vishwas R. Acharya*, Manju Singh, R. K. Patel, Lakshay Goyal \\ Department of Genetics and Plant Breeding, N. M. College of Agriculture, Navsari \\ Agricultural University, Navsari- 396450 Gujarat, India \\ *Corresponding author
}

\begin{tabular}{|l|}
\hline Key w o r d s \\
Variability, GCV, \\
PCV, Genetic \\
advance
\end{tabular}

A B S T R A C T

The variability is the soul of any breeding programme, so, in this research an attempt was made to assess the morphological variability using thirteen characters in coriander. The values of heritability in broad sense were observed very high for total oil content followed by days to $50 \%$ flowering, days to maturity, 1000 - seed weight, seed yield per plant, umbels per plant, seeds per plant, seeds per umbel and plant height. Genetic advance as percentage of mean ranged between $0.67 \%$ for primary branches per plant, to $78.27 \%$ for umbels per plant. Genetic advance as per cent of mean was observed high for umbels per plant, seed yield per plant, seeds per plant, total oil content, 1000 - seed weight, days to 50\% flowering and plant height. In the present findings phenotypic coefficient of variations were observed to be higher than the corresponding genotypic coefficient of variation for all the characters studied, also results indicated that high heritability coupled with high genetic advance and moderate to high GCV and PCV were recorded indicating the role of additive gene action in the inheritance of these traits, hence further improvement in these characters would be achieved by phenotypic selection.

\section{Introduction}

Coriander (Coriandrum sativum L.) is an important spice resides a prime position in flavouring food which belongs to family Apiaeceae (Umbelliferae) and having a somatic chromosome number $2 \mathrm{n}=22$. Coriander is native to the Mediterranean and Middle East, also found wild in Egypt and Sudan. Now it is widely cultivated India as well as in the world for its demand of both seeds and leaves as a spice and herb, respectively.

Coriander is an annual, herbaceous, cross pollinated crop attaining height from 20-120 $\mathrm{cm}$. The flowers are andromonoecious, small whitish or pinkish purple, born on compound terminal umbels with protoandrous condition thus; it is difficult to handle for controlled 
pollination. The upper leaves are wispy and finely divided, the lower ones broad, undivided and trilobite. The fruits are cremocarp globular and ribbed with brownish yellow in colour and range in size from 1.5 to $5.0 \mathrm{~mm}$ in diameter and when pressed, they separate into two halves of mericarps each containing a seed.

The entire plant of coriander is used in preparing chutney, where, the leaves are used for its flavouring the curries, sauce and soups. The volatile essential oil compositions like terpenoids and phenolic constituents, which are of great importance in the field of pharmacology. In addition, C. sativum alone or in combination with other herbal agents are recommended for dyspeptic complaints, loss of appetite, convulsion, insomnia and anxiety also found to improve blood glucose control and thus it held promise for use as an antihyperglycemic agent (Mandal et al., 2015). The fresh green seeds of coriander is also used to make 'Dhana dal' which is very popular in Gujarat state.

Knowledge of genetic variability on its nature and degree is useful for selecting desirable genotypes from a germplasm for the successful breeding programme. The value of germplasm collection depends not only on the number of accessions but also up on the genetic diversity present in those accessions. The observed variability is a combined estimate of genetic and environmental causes of which only the genetic variability is heritable. However, the estimate of heritability alone does not provide an idea of the expected gain in the next generation but it has to be considered in conjunction with genetic advance. Keeping this in view, the present investigation was made to explore the genetic variability, by determining the magnitude of genetic coefficient of variation, heritability estimates and expected genetic advance of different biometric traits effects in 28 coriander varieties.

\section{Materials and Methods}

The experimental material comprised of 28 coriander varieties having two check variety viz., Hissar Anand and Rcr-728 were sown during Rabi 2017-18 under Randomized Complete Block Design with three replications at the Research Farm, Genetics and Plant Breeding, N.M.C.A. NAU, Navsari. It situated at $20^{\circ} 55^{\circ}$ North latitude and $72^{\circ}$ 53' East longitudes in zone-I South Gujarat (heavy rainfall).In experiment, each plot consisted of 120 plants at $30 \times 15 \mathrm{~cm}^{2}$ inter and intra row spacing. All the recommended package of practices were adopted for raising a successful and healthy crop.

In each replication and in each treatment five plants were randomly selected and tagged for observation. Periodically, observations recorded on days to $50 \%$ flowering, Days to maturity, Plant height $(\mathrm{cm})$, Primary branches per plant, Secondary branches per plant, Umbels per plant, Umbellets per umbel, Seeds per umbel, Seeds per plant, Seed yield per plant (g), 1000-seed weight (g), Harvest index $(\%)$ and Total oil content $(\%)$. The data recorded for all the characters were subjected to analysis of variance with the formula suggested by Panse and Sukhatme (1978).

Phenotypic and genotypic components of variance and phenotypic and genotypic coefficient of variation were estimated by applying the formula as suggested by Cockerham (1963). Heritability as per the formula given by Allard (1960) and genetic advance for each character was predicted by the formula given by Johnson et al., (1955).

\section{Results and Discussion}

The analysis of variance for all the characters revealed highly significant differences among the genotypes studied except primary branches per plant, indicated sufficient amount of variability present among twenty- 
eight genotypes of coriander under study (Table 1).

High genotypic as well as phenotypic variances depicted by seeds per plant, umbels per plant, days to maturity and plant height. The genotypic coefficient of variation was recorded the highest for umbels per plant followed by seed yield per plant, seeds per umbel, seeds per plant, 1000 - seed weight and total oil content. . In contrast to plant height and harvest index similar higher magnitude of GCV and PCV was reported by Verma (2014), Gauhar et al., (2018) and Anilkumar et al., (2018). The moderate amount of genotypic coefficient of variation was observed for secondary branches per plant, plant height, primary branches per plant, days to $50 \%$ flowering, umbellets per umbel and harvest index. Similarly, moderate estimate of GCV and PCV was reported for primary branches per plant by Dhakad et al., (2017), Mishra et al., (2017) and Verma et al., (2018);; for plant height, secondary branches per plant and umbellets per umbel (for GCV) by Gauhar et al., (2018) and Dhakad et al., (2017). This indicated considerable amount of variability in the materials for these traits.

The higher estimates of heritability was recorded for total oil content followed by days to $50 \%$ flowering, days to maturity, 1000 seed weight, seed yield per plant, umbels per plant, seeds per plant, seeds per umbel and plant height. Similar results of high heritability was reported by Dhakad et al., (2017) and Verma et al., (2018) for plant height, days to maturity, seed yield per plant, umbels per plant,1000 - seed weight and seeds per umbel and days to 50\% flowering was reported by Gauhar et al., (2018). Harvest index and umbellets per umbel manifested moderate heritability. This indicated that characters were less influenced by environment and direct selection for these traits would be effective for further improvement. Low heritability with low genetic advance was observed for primary branches per plant indicating its poor response to selection.

Heritability estimates along with genetic gains are more effective and reliable in predicting the improvement through selection. Estimates of genetic advance in general help to predict the extent of improvement that can be achieved for improving different characters. Genetic advance as percentage of mean was calculated to predict the genetic gain. Genetic advance as per cent of mean was observed high for umbels per plant, seed yield per plant, seeds per plant, total oil content, 1000 seed weight, days to $50 \%$ flowering and plant height. High heritability coupled with high genetic advance as per cent of mean was reported for umbels per plant, seed yield per plant, seeds per umbel and plant height by Singh and Singh (2013), Dhakad et al., (2017) and Verma et al., (2018); for 1000 - seed weight by Gauhar et al., (2018) and Anilkumar et al., (2018).

High heritability were also coupled with high genetic advance as per cent of mean for these traits which indicated the predominance of additive gene effects, thus more emphasis should be given to mass selection and progeny selection for further improvement of these characters.

It could be concluded from the present study that, while imposing selection for genetic improvement of seed yield per plant in coriander, due weightage should be given to umbels per plant followed by seeds per plant, 1000 - seed weight, umbellets per umbel and harvest index. Further it was found that genotypes viz., NVC-11 followed by NVC-10 and NVC-13 having good mean value of seed yield per plant. Use of these characters in breeding programme will help in developing genotypes having high yield. 
Table.1 Mean sum of squares from analysis of variance for thirteen different characters of coriander

\begin{tabular}{|c|c|c|c|c|c|c|c|c|}
\hline $\begin{array}{l}\text { Source of } \\
\text { variation }\end{array}$ & df & $\begin{array}{c}\text { Days to } \\
50 \% \\
\text { flowering }\end{array}$ & $\begin{array}{l}\text { Days to } \\
\text { maturity }\end{array}$ & $\begin{array}{l}\text { Plant height } \\
(\mathrm{cm})\end{array}$ & $\begin{array}{l}\text { Primary } \\
\text { branches } \\
\text { per plant }\end{array}$ & $\begin{array}{l}\text { Secondary } \\
\text { branches } \\
\text { per plant }\end{array}$ & $\begin{array}{c}\text { Umbels per } \\
\text { plant }\end{array}$ & $\begin{array}{l}\text { Umbellets } \\
\text { per umbel }\end{array}$ \\
\hline Replication & 2 & $16.75 * *$ & $24.79 * *$ & $1083.58 * *$ & 0.25 & 0.72 & $66.44 *$ & $2.60 * *$ \\
\hline Genotypes & 27 & $152.82 * *$ & $112.76 * *$ & $295.83 * *$ & 0.33 & $2.25 *$ & $278.55 * *$ & $0.86 * *$ \\
\hline Error & 54 & 2.20 & 3.24 & 51.07 & 16.83 & 1.12 & 19.21 & 0.36 \\
\hline S. Em \pm & & 0.85 & 1.03 & 4.12 & 0.32 & 0.61 & 2.53 & 0.34 \\
\hline C.D at $5 \%$ & & 2.43 & 2.94 & 11.69 & - & 1.73 & 7.17 & 0.98 \\
\hline C.V\% & & 2.96 & 1.68 & 10.19 & 14.61 & 16.68 & 19.80 & 11.75 \\
\hline
\end{tabular}

\begin{tabular}{|l|c|c|c|c|c|c|c|}
\hline $\begin{array}{l}\text { Source of } \\
\text { variation }\end{array}$ & df & $\begin{array}{c}\text { Seeds per } \\
\text { umbel }\end{array}$ & $\begin{array}{c}\text { Seed per } \\
\text { plant }\end{array}$ & $\begin{array}{c}\text { Seed yield per } \\
\text { plant }(\mathbf{g})\end{array}$ & $\begin{array}{c}\text { 1000- seed } \\
\text { weight }(\mathbf{g})\end{array}$ & $\begin{array}{c}\text { Harvest index } \\
(\boldsymbol{\%})\end{array}$ \\
\hline Replication & 2 & 14.58 & 370.94 & 0.054 & 0.23 & 27.37 & 0.065 \\
\hline Genotypes & 27 & $59.71 * *$ & $8889.07 * *$ & $3.69 * *$ & $34.99 * *$ & $58.47 * *$ & $35.26 * *$ \\
\hline Error & 54 & 7.74 & 983.44 & 0.23 & 1.22 & 10.78 & 0.32 \\
\hline S.Em \pm & & 1.60 & 18.10 & 0.63 & 1.89 & 0.28 & 0.32 \\
\hline C.D at 5\% & & 4.55 & 51.33 & 0.79 & 1.81 & 5.37 & 0.92 \\
\hline C.V\% & & 16.73 & 15.35 & 16.74 & 6.70 & 8.13 & 3.51 \\
\hline
\end{tabular}

$*, * *$ Significant at $5 \%$ and $1 \%$ level respectively 
Table.2 Range, mean and components of variance for thirteen different characters of coriander

\begin{tabular}{|c|c|c|c|c|c|c|}
\hline \multirow{2}{*}{$\begin{array}{l}\text { Sr. } \\
\text { No }\end{array}$} & \multirow[t]{2}{*}{ Character } & \multirow[t]{2}{*}{ Range } & \multirow[t]{2}{*}{ Mean } & \multicolumn{3}{|c|}{ Component of variance } \\
\hline & & & & $\sigma_{e}^{2}$ & $\sigma_{e}^{2}$ & $\sigma_{e}^{2}$ \\
\hline 1 & Days to $50 \%$ flowering & $38.00-67.33$ & 50.37 & 50.20 & 52.41 & 2.20 \\
\hline 2 & Days to maturity & $96.00-121.33$ & 106.90 & 36.50 & 39.74 & 3.24 \\
\hline 3 & Plant height $(\mathrm{cm})$ & $52.66-91.33$ & 70.11 & 81.58 & 132.66 & 51.07 \\
\hline 4 & Primary branches per plant & $3.0-4.33$ & 3.82 & 0.00 & 0.31 & 0.31 \\
\hline 5 & Secondary branches per plant & $4.66-8.00$ & 6.34 & 0.37 & 1.50 & 1.12 \\
\hline 6 & Umbels per plant & $13.00-53.33$ & 22.13 & 86.44 & 105.66 & 19.21 \\
\hline 7 & Umbellets per umbel & $4.00-6.33$ & 5.10 & 0.16 & 0.52 & 0.36 \\
\hline 8 & Seeds per umbel & $11.00-28.67$ & 16.63 & 17.32 & 25.0 & 7.74 \\
\hline 9 & Seed per plant & $113.67-377.67$ & 204.19 & 2635.20 & 3618.65 & 983.44 \\
\hline 10 & 1000-seed weight $(\mathrm{g})$ & $11.33-23.73$ & 16.52 & 11.25 & 12.48 & 1.22 \\
\hline 11 & Seed yield per plant (g) & $1.57-6.67$ & 2.90 & 1.15 & 1.38 & 0.23 \\
\hline 12 & Harvest index (\%) & $28.03-46.56$ & 40.37 & 15.89 & 26.68 & 10.78 \\
\hline 13 & Total oil content $(\%)$ & $11.36-24.26$ & 16.12 & 11.64 & 11.97 & 0.32 \\
\hline
\end{tabular}


Table.3 Genotypic and phenotypic coefficients of variation, heritability, genetic advance as per cent of mean for thirteen different characters of coriander

\begin{tabular}{|c|c|c|c|c|c|}
\hline $\begin{array}{l}\text { Sr. } \\
\text { no. }\end{array}$ & Characters & GCV \% & PCV \% & $\begin{array}{c}\text { Heritability } \\
(\text { Broad sense \% })\end{array}$ & $\begin{array}{c}\text { Genetic } \\
\text { advance } \\
\text { (\% of mean) }\end{array}$ \\
\hline $\mathbf{1}$ & Days to $50 \%$ flowering & 14.46 & 14.16 & 95.79 & 28.55 \\
\hline 2 & Days to maturity & 5.89 & 5.65 & 91.84 & 11.15 \\
\hline 3 & Plant height $(\mathrm{cm})$ & 16.42 & 12.88 & 61.49 & 20.81 \\
\hline 4 & Primary branches per plant & 14.77 & 2.19 & 2.21 & 0.67 \\
\hline 5 & Secondary branches per plant & 19.30 & 9.70 & 25.27 & 10.05 \\
\hline 6 & Umbels per plant & 46.44 & 42.01 & 81.81 & 78.27 \\
\hline 7 & Umbellets per umbel & 14.23 & 8.03 & 31.86 & 9.34 \\
\hline 8 & Seeds per umbel & 30.10 & 25.02 & 69.10 & 42.85 \\
\hline 9 & Seed per plant & 29.46 & 25.14 & 72.82 & 44.19 \\
\hline 10 & 1000-seed weight (g) & 21.37 & 20.30 & 90.16 & 39.71 \\
\hline 11 & Seed yield per plant (g) & 40.56 & 36.94 & 82.95 & 69.32 \\
\hline 12 & Harvest index (\%) & 12.79 & 9.87 & 59.58 & 15.70 \\
\hline 13 & Total oil content $(\%)$ & 21.45 & 21.16 & 97.31 & 43.00 \\
\hline
\end{tabular}




\section{References}

Allard, R. W. (1960). Principles of Plant Breeding. John Wiley and sons, New York. 485p.

Anilkumar, G.S., Umesha, K., Shivapriya, M., Halesh, G.K. and Nithin kumar, V.C. (2018) Genetic Variability, Heritability and Genetic Advance Studies in Coriander (Coriandrum sativum L.), Int . J. Pure App. Biosci., 6(3): 426-430.

Cockerham, C. C. (1963). Estimation of genetic variance in statistical Genetics and Plant breeding. National research council, Washington, DC, p.53.

Dhakad, S. R., Sengupta, SK., Lal, N., Shiurkar, G. (2017). Genetic diversity and heritability analysis in coriander. The Pharma Innovation Journal. 6(8): 40-46.

Gauhar, T., Solanki, R. K., Kakani, R. K., and Choudhary, M. (2018). Variability and character association studies in coriander (Coriandrum sativum L.). International J. Seed Spices, 8(1), $36-40$

Johnson, H. W., Robinson, H. R., and Comstock, R. E. (1955). Estimation of genetic and environmental variability in soybean (Glycine $\max$ L.). Agron. J.,
47: 314-318.

Mandal, S., and Mandal, M. (2015). Coriander (Coriandrum sativum L.) essential oil: Chemistry and biological activity. Asian Pacific Journal of Tropical Biomedicine, 5(6): 421-428.

Mishra, T. D. and Balaji Vikram (2017) Genetic Variability, Heritability and Character Association in Coriander Genotypes (Coriandrum sativum L.) under Allahabad Agro-Climatic Condition. Int. J. Pure App. Biosci. 5(3):151-158

Panse, V. G. and Sukhatme, P. V. (1978). Statistical methods for agricultural workers. ICAR, New Delhi, pp. 103108.

Verma, M., Pandey, V., Singh, D., Kumar, S. and Kumar, P. (2018) Studies on genetic variability in germplasm of coriander (Coriandrum sativum L.) Journal of Pharmacognosy and Phytochemistry, SP1: 2490-2493

Verma, P., Doshi, V. and Solanki, R. K. (2014). Genetic variability assessed in coriander (Coriandrum sativum L.) over years under environmental conditions of south Eastern Rajasthan. International J. Seed Spices, 4(2): 94-95.

\section{How to cite this article:}

Vishwas R. Acharya, Manju Singh, R. K. Patel, Lakshay Goyal. 2020. Genetic Diversity of Coriander for Yield and its Attributing Characters. Int.J.Curr.Microbiol.App.Sci. 9(02): 222228. doi: https://doi.org/10.20546/ijcmas.2020.902.028 